\title{
A Comparative Study on the Determination of Biochemical Changes of Different Species of Fish During
}

\section{Frozen Storage}

\author{
Nasrin Akter 1,*iD, Khan Md. Murtaja Reza Linkon ${ }^{1}$, Md. Mahbubur Rahman ${ }^{1}$, \\ Md. Shahadat Hossain ${ }^{1}$
}

1 Department of Food Technology and Nutritional Science, Mawlana Bhashani Science and Technology University, Santosh, Tangail-1902, Bangladesh

* Correspondence: nasrinrupa.ftns@gmail.com;

Scopus Author ID 34879354400

Received: 20.06.2020; Revised: 5.07.2020; Accepted: 5.07.2020; Published: 8.07.2020

\begin{abstract}
The main purpose of the study was to observe the nutritional value of unfrozen fish such as Rui (Labeo rohita), Catla (Catla catla), Mrigal carp (Cirrhinus cirrhosus) and to evaluate the effect of freezing condition for $1 \mathrm{st}, 2 \mathrm{nd}$ and $3 \mathrm{rd}$ weeks at $\left(-18{ }^{\circ} \mathrm{C}\right)$. The average body weights of the samples were $900 \mathrm{gm}, 800 \mathrm{gm}$, and $950 \mathrm{gm}$ for Rui, Catla, and Mrigal, respectively. All fish samples collected from the regional market of Tangail and Rangpur district in Bangladesh. The samples were analyzed after a week interval of up to three weeks. The moisture content of natural and cultivated rui, catla and mrigal were $77.06 \%, 73.50 \%, 75.21 \%$ and $75.70 \%, 74.41 \%, 74.35 \%$ respectively in normal condition. These decreased with rising freezing time in 3rd weeks. There were $73.66 \%, 72.41 \%, 73.97 \%$, and $71.30 \%, 73.15 \%, 72.06 \%$, respectively. In addition, The protein content of natural and cultivated rui, catla and mrigal were noticed $18.55 \%, 20.19 \%, 19.85 \%$ and $17.34 \%, 19.45 \%, 19.35 \%$ respectively in normal condition and these declined with increasing frozen storage on 3rd weeks, these values were $17.15 \% 18.25 \%, 17.50 \%$ and $16 \% 17.65 \%, 17.48 \%$ respectively. Moreover, the lipid content of natural and cultivated rui, catla and mrigal were $1.29 \%, 2.50 \%, 1.33 \%$, and $5.67 \%, 4 \%, 4.78 \%$ respectively in normal condition and after 3rd weeks there were $0.60 \% 1.48 \%, 1.15 \%$ and $5 \%, 2.8 \%, 4.2 \%$ respectively. The ash content of natural and cultivated rui, catla and mrigal were $0.99 \%, 1.28 \%, 0.88 \%$ and $0.95 \%, 0.81 \%, 0.91 \%$ in unfrozen condition and $1.20 \%, 1.88 \%, 1.80 \%$ and $1.24 \%, 1.92 \%, 1.73 \%$ respectively were observed after three weeks. The maximum values of extract release volume, swelling capacity recorded for fresh samples and decreased with freezing times. However, at the end of the study, remarkable change was observed between a normal sample and frozen samples after one, two, and three weeks. Finally, the study showed that the biochemical composition of fish muscles influenced by freezing temperature and time.
\end{abstract}

Keywords: Nutritive Value; Moisture content; lipid content; ash content; protein content.

Abbreviations: $\mathrm{R}-\mathrm{N}=\mathrm{Rui}$ natural, $\mathrm{R}-\mathrm{C}=\mathrm{Rui}$ cultivated; $\mathrm{C}-\mathrm{N}=\mathrm{Catla}$ natural, $\mathrm{C}-\mathrm{C}=$ Catla cultivated; $\mathrm{M}-\mathrm{N}=$ Mrigal carp natural, $\mathrm{M}-\mathrm{C}=$ Mrigal carp cultivated.

(C) 2020 by the authors. This article is an open-access article distributed under the terms and conditions of the Creative Commons Attribution (CC BY) license (https://creativecommons.org/licenses/by/4.0/).

\section{Introduction}

Fish is one of the most important sources of animal protein available in the tropics and has been widely accepted as a good source of protein and other elements for the maintenance of a healthy body [1]. The fish diet has high commercial and medicinal values [2]. Fish also have economic value but rich in nutritional value are often not and mineral-rich food $[3,4]$. Fish 
has been playing an important role in addressing the nutritional and livelihood security of people in developing countries. Besides, fish is rich in macronutrients such as proteins, lipids, and ash and micronutrients like vitamins and minerals [5]. The micronutrient content of fish can varies on some factors, such as species, environmental conditions, whether they are wildcaught or farmed, and other characteristics [6]. Although fish is highly nutritious, yet it is one of the most rapid perishable foods because of its short shelf life. The quality of highly perishable fresh food like fish continuously changes during storage. During the post-harvest period, especially the fish of the tropical countries, including Bangladesh, undergo deteriorative changes very quickly due to enzymatic and bacterial action.

In Bangladesh, fish in a fresh condition is not available because the major fishing ground is far away from the cities and the consuming center, which is not easily accessible. Nowadays, the fish industry has to face one of the major problems for the inadequate management of fish processing waste or by-products [7]. Nowadays, one of the most active areas of nanoclays research is their employ in food packaging. Then critical issues in developing food packaging materials are reviewed to minimize gasses and other small molecules transfer between out-side packaging environment and food [8]. The extension of shelf life can be achieved by freezing, chilling, salting, smoking, glazing, etc. Among the various techniques of preservation, freezing is considered to be the only long term method which can preserve a fish with a minimum change in its quality these mean that fish if necessary should be stored, for a short period to retain the taste, and provide both the protein and lipid at an optimal level. Consumers usually buy fish in bulk and store in the refrigerator. Freezing and cold storage can play a vital role in retarding deteriorative changes to a certain period of time [9]. However, when seafood is frozen and stored in a frozen state, it necessarily loses quality [10]. Loss in the quality of frozen stored fish is mainly due to changes in muscle integrity, proteins, and lipids [11]. Various changes occurred, such as denaturation, coagulation, reduction of protein digestibility, rancidity, and loss of vitamins during frozen storage that have an overall effect on the quality of frozen food [12]. The quality of fish is connected with the level of freshness of the fish. The freshness and nutritional value of yellowfin and skipjack tuna were declined during six months of storage [13]. Carrera et al.[14] studies revealed that the quality loss of European hake (Merluccius merluccius) during frozen storage.

Rui (Labeo rohita), Catla (Catla catla), and Mrigal crap (Cirrhinus cirrhosis) are very commonly eaten in Bangladesh, in addition to Pakistan, Sri Lanka and the Indian states of Tripura, Bihar, Odisha, Assam, West Bengal, and Uttar Pradesh. It has a massive demand in the Asian market and contributing much to the total fish production and economic growth of some Asian countries, such as Bangladesh and India. The primary purpose of this study is to evaluate the nutritional value of natural and cultivated Labeo rohita, Catla catla, and Cirrhinus cirrhosus in fresh muscle and frozen storage after 1st, 2nd, and 3rd weeks.

\section{Materials and Methods}

\subsection{Sample collection.}

Fish species were divided into two groups natural and cultivated. All-natural fish were collected from various ponds at Rangpur district in Bangladesh, and cultivated fish were collected from Tangail, Dhaka, Bangladesh. The collected fresh fish samples were kept immediately in ice on polyethylene bags and transported to the laboratory of the Department of Food Technology and Nutritional Science, Mawlana Bhashani Science and Technology 
University, Santosh, Tangail-1902. Samples were examined during the period of December 2016 to May 2017. Fish were cleaned with deionized-distilled water and remove all fins, viscera after that muscle tissue was taken from the dorsal part of fish. All samples were kept in cold storage at a temperature $-18{ }^{\circ} \mathrm{C}$ for different times (1st, 2nd, and 3rd weeks) until biochemical analysis. Samples were analyzed for the biochemical composition of the dried tissues.

\subsection{Biochemical analysis.}

Proximate analyses such as moisture, lipid, and protein contents were carried out following the methods of AOAC (1984). Protein, lipid, moisture, and ash of the samples were determined according to the Kjeldahl method, Solvent extraction method, and Oven-dry methods, respectively. Besides extract release volume (ERV) was determined by based upon the amount of aqueous extract released by a homogenate of fish when it is allowed to pass through filter paper for a given period. Similarly, swelling capacity (SW) was determined by the use of the modified filter-paper press technique.

\section{Results and Discussion}

The nutrient composition of fish depends on fish species, gender, health, age, nutritional factor, and time of the year [15]. It is noticeable that the average protein content of fish is $15 \%-$ $30 \%$, lipids $0 \%-25 \%$, and 50\%-80\% moisture. Although, depending on their fat content, there are some lean fish such as cod and hake, this nutrient composition can vary [16]. The nutrient composition of Labeo rohita, Catla catla, and Cirrhinus cirrhosus at the fresh condition and frozen condition at every seven days interval has been shown in the following tables $(1,2$, and $3)$.

\subsection{Total moisture content.}

In findings, maximum moisture contents found $77.06 \%, 74.41 \%$, and $75.21 \%$ for Rui, Catla, and Mrigal crap fish in fresh muscle. In comparison, the minimum values were recorded at $71.30 \%, 72.41 \%$, and $72.06 \%$ after three weeks of freezing. These findings are similar to Gandotra et al. [17] showed that the moisture content of Labeo Rohita was found $84.74 \pm 0.1 \%$ on the first day. The value was $80.84 \pm 0.09 \%$ on the last day (21) of storage at $-12 \pm 20 \mathrm{C}$. The results illustrated that there was $1.08 \%, 2.70 \%$, and $4.60 \%$ decline of moisture content on $1 \mathrm{st}$, 2nd, and 3rd weeks, respectively. According to Nurullah et al. [18] the average moisture content of punti fish is $72.97 \%$ in unfrozen conditions. After a week, it is reduced $75.77 \%$ in frozen condition. On the other hand, Siddique et al. [19] found an upward trend in Puntius sp. whereas, that moisture content remained stable for 2 weeks in Kirschnik et al. [20] study samples of a tail. The amount of moisture content could differ because of their different size, processing method, temperature, season, etc. [21].

\subsection{Total ash content.}

The present study showed that the ash contents were found in fresh fish species in $1.24 \%, 1.92 \%$, and $1.80 \%$. After three weeks of storage at freezing temperature $-18^{\circ} \mathrm{C}$ a small amount of ash was decreased from the fresh fish, and the highest amount of ash content was found $0.95 \%, 0.81 \%$, and $0.88 \%$. Gandotra et al. [17] depicted that ash content reduced from 
$1.79 \pm 0.01 \%$ to $1.36 \pm 0.03 \%$ on 3 rd week of storage at $-12 \pm 20 \mathrm{C}$, which is almost similar to the present study. On the contrary, Arannilewa et al. [22] and Saulum [23] observed that the ash content remained the same in tilapia and carp fish throughout the 60 days and 21 days of frozen storage. Minerals are a very important element that is found in ash content. According to Beklevik et al. [24], decrease in ash content was attributed to the drip loss during the thawing process. This might be due to loss of minerals content from the cell of fresh raw fish during storage at low temperature $\left(-18^{\circ} \mathrm{C}\right)$ - the variation of ash content of natural and cultivated because of fish feed, using drugs.

\subsection{Total protein content.}

The maximum protein contents $18.55 \%$ and $17.34 \%$ were recorded for natural and cultivated Rui fish in fresh while the minimum values were $17.15 \%$ and $16 \%$ after three weeks of freezing. As well as maximum moisture contents, $20.19 \%$ and $19.45 \%$ were recorded for catla and $19.85 \%$ and $19.35 \%$ for mrigal crap in fresh while the minimum values were $18.25 \%$, and $17.65 \%$ for catla $17.5 \%$ and $17.48 \%$ for mrigal crap after three weeks of freezing. There were no remarkable changes between the unfrozen fish and two weeks of frozen storage. Gandotra et al. [17] depicted that the highest protein content of Labeo Rohita was recorded for fresh (unfrozen) fish samples, and the lowest protein content was recorded for fish samples stored for 3rd weeks. Siddique et al. [19] on Puntius sp. revealed that after three weeks of frozen storage, protein declined in a significant manner of Labeo rohita at $-50{ }^{\circ} \mathrm{C}$ for 21 days. This deviation may occur due to feeding ability, habits of feeding, fasting during spawning and migration etc. [25]. In addition, protein content decreased for denaturation and loss in gelatin proteins. Xiong [26] Zamir et al. [27] and Saeed \& Howell [28] depicted that proteins are exposed to oxidizing environments, which are very susceptible to a chemical modification that results in declined protein content. High protein content based on different protein sources develops hardness during storage, particularly at high temperatures, but more pronounced hardness develops on the use of Milk protein concentrates [29].

\subsection{The total lipid content.}

It was observed that the highest amount of lipid contents were found at $5.67 \%, 4 \%$, and $4.78 \%$ respectively in cultivated fish at normal condition. Three weeks later a small amount of lipid was reduced at freezing temperature $-18^{\circ} \mathrm{C}$. This result comes in agreement with Arannilewa et al. [22] and Siddique et al. [19] in found that when Tilapia and Puntius sp. stored at low temperature a significant loss in lipid occurred. In unfrozen condition, the lipid content of Ruhu (Labeo rohita), grass carp (Ctenopharyngodon idella), and Tilapia (Oreochromis mossambica) were $5.12 \%, 4.61 \%, 2.55 \%$ respectively. In the freezing condition, these values were $3.31 \%, 2.8 \%$, and $1.83 \%$ because of various temperatures, freezing time, location size [30]. On the other hand, lipid content may also fluctuate due to seasonal and geographic location [31]. When clams (Venerupis decussata) stored at refrigerated temperature for 1,3, and 6 months the amounts of moisture and lipid contents gradually decreased compared with fresh samples [32]. During cold storage Sustainable amount of semen quality reduced due to the harmful effects of primary and secondary peroxidative products [33]. 


\subsection{Total extract release volume and swelling capacity.}

The present study showed that the highest amount of extract release volume (ERV) and Swelling Capacity (SC) were found in fresh condition. After one, two, and three weeks of storage at freezing temperature $\left(-18^{\circ} \mathrm{C}\right)$, a small amount of extract release volume and Swelling capacity were decreased. This might be due to the loss of water from the cell wall or protein denaturation of fresh raw fish during storage at low temperature $\left(-18^{\circ} \mathrm{C}\right)$ - extract release volume decrease when meats undergo spoilage [32]. There is a little change occurred in the water holding capacity (WHC) while precooling the material at freezing point and decreasing product temperature under the freezing temperature [33].

Table 1. Effect of freezing on the proximate composition of Rui (Labeo rohita) at different freezing time.

\begin{tabular}{l|l|l|l|l|l|l|l|l}
\multirow{2}{*}{ Name of the test } & \multicolumn{3}{l}{ unfrozen } & After $1^{\text {st }}$ week & \multicolumn{2}{l}{ After $2^{\text {nd }}$ weeks } & After $3^{\text {rd }}$ weeks \\
\cline { 2 - 10 } & R-N & R-C & R-N & R-C & R-N & R-C & R-N & R-C \\
\hline Moisture (\%) & 77.06 & 75.70 & 75.94 & 74.83 & 75.61 & 74.29 & 73.66 & 71.30 \\
\hline Ash (\%) & 1.24 & 1.20 & 1.21 & 1.11 & 1.12 & 1.10 & 0.95 & 0.99 \\
\hline Protein (\%) & 18.55 & 17.34 & 18.10 & 17.00 & 17.65 & 16.45 & 17.15 & 16 \\
\hline Lipid (\%) & 1.29 & 5.67 & 1.14 & 5.37 & 0.60 & 5.31 & 0.60 & 5 \\
\hline ERV(ml) & 40 & 39 & 35 & 32 & 28 & 31 & 26 & 30 \\
\hline SC $(\%)$ & 185.72 & 200 & 171.43 & 185.72 & 157.14 & 142.85 & 128.57 & 114.28
\end{tabular}

Table 2. Effect of freezing on the proximate composition of Catla (Catla catla) at different freezing time.

\begin{tabular}{l|l|l|l|l|l|l|l|l}
\multirow{2}{*}{ Name of the test } & \multicolumn{2}{l}{ unfrozen } & \multicolumn{2}{l}{ After $1^{\text {st }}$ week } & \multicolumn{2}{l}{ After $2^{\text {nd }}$ weeks } & \multicolumn{2}{l}{ After $3^{\text {rd }}$ weeks } \\
\cline { 2 - 10 } & C-N & C-C & C-N & C-C & C-N & C-C & C-N & C-C \\
\hline Moisture (\%) & 73.50 & 74.41 & 73.21 & 73.88 & 72.83 & 73.99 & 72.41 & 73.15 \\
\hline Ash (\%) & 1.92 & 1.88 & 1.78 & 1.6 & 1.09 & 1.5 & 0.81 & 1.28 \\
\hline Protein (\%) & 20.19 & 19.45 & 19.50 & 19 & 18.90 & 18.50 & 18.25 & 17.65 \\
\hline Lipid (\%) & 2.50 & 4 & 2.16 & 3.32 & 1.57 & 2.86 & 1.48 & 2.8 \\
\hline ERV $(\mathrm{ml})$ & 39 & 50 & 30 & 49 & 29 & 45 & 28 & 40 \\
\hline SC $(\%)$ & 214.29 & 200 & 200 & 185.72 & 185.72 & 157.14 & 157.14 & 142.85
\end{tabular}

Table 3. Effect of freezing on proximate composition of Mrigal carp (Cirrhinus cirrhosis) at different freezing time.

\begin{tabular}{l|l|l|l|l|l|l|l|l}
\multirow{2}{*}{ Name of the test } & \multicolumn{2}{|l|}{ unfrozen } & \multicolumn{2}{l}{ After 1st week } & \multicolumn{2}{l}{ After2nd weeks } & \multicolumn{2}{l}{ After 3rd weeks } \\
\cline { 2 - 9 } & M-N & M-C & M-N & M-C & M-N & M-C & M-N & M-C \\
\hline Moisture (\%) & 75.21 & 74.35 & 74.56 & 73.64 & 74.04 & 73.29 & 73.97 & 72.06 \\
\hline Ash (\%) & 1.73 & 1.80 & 1.62 & 1.41 & 0.95 & 1.23 & 0.91 & 0.88 \\
\hline Protein (\%) & 19.85 & 19.35 & 19.00 & 18.84 & 18.45 & 18 & 17.50 & 17.48 \\
\hline Lipid (\%) & 1.33 & 4.78 & 1.26 & 4.50 & 1.18 & 4.22 & 1.15 & 4.20 \\
\hline ERV(ml) & 60 & 30 & 52 & 29 & 45 & 27 & 40 & 21 \\
\hline SC (\%) & 214.19 & 171.43 & 200 & 157.14 & 185.72 & 142.85 & 157.14 & 114.28
\end{tabular}

\section{Conclusions}

The main findings of this study were to examine the change of nutritional value such as moisture, ash, protein, lipid, extract release volume, and swelling capacity in different species of Labeo rohita, Catla catla and Cirrhinus cirrhosis at freezing time. It has some effect on the nutrient compositions of the selected three species, which was taken under the experiment. To observe this study, it revealed that there were few changes in the biochemical composition of Labeo rohita, Catla catla, and Cirrhinus cirrhosis in frozen condition after three weeks. This kind of deterioration was occurred with freezing time in addition to protein denaturation, lipid hydrolysis, and oxidation proliferation of bacteria also noticeable. Fish species enriched with protein, but the protein content dropped with processing and storage time; however, for long-time preservation, freezing is the best method when a nutrient is a focus. To conclude that it may consume the fish after freezing, but getting the best quality nutrition fish should be consumed in fresh condition as early as possible. 


\section{Funding}

This research received no external funding.

\section{Acknowledgments}

The authors are grateful who have participated in this research work.

\section{Conflicts of Interest}

The authors declare no conflict of interest.

\section{References}

1. Aberoumand, A. Impact of freezing on nutritional composition of some less known selected fresh fishes in Iran. International food research journal 2013, 20, 347.

2. Nunes, M.L.; Batista, I.; De Campos, R.M. Physical, chemical and sensory analysis of sardine (Sardina pilchardus) stored in ice. Journal of the Science of Food and Agriculture 1992, 59, 37-43, https://doi.org/10.1002/jsfa.2740590106.

3. Moghaddam, H.; Mesgaran, M.; Jahanian, H.; Jahanian, R. Determination of Chemical Composition, Mineral Contents, and Protein Quality of Iranian Kilka Fish Meal. International Journal of Poultry Science 2007, 6, 354-361, https://doi.org/10.3923/ijps.2007.354.361.

4. Asuquo, F.E.; Ewa-Oboho, I.; Asuquo, E.F.; Udo, P.J. Fish Species Used as Biomarker for Heavy Metal and Hydrocarbon Contamination for Cross River, Nigeria. Environmentalist 2004, 24, 29-37, https://doi.org/10.1023/B:ENVR.0000046344.04734.39.

5. Balami, S.; Sharma, A.; and Karn, R. Significance of nutritional value of fish for human health. Malaysian Journal of Halal Research 2019, 2, 32-34, https://doi.org/10.2478/mjhr-2019-0012.

6. Hicks, C. C.; P, J. Cohen.; N, A. Graham.; K, L. Nash.; E, H. Allison.; C, D’Lima.; D, J. Mills.; M, Roscher.; S, H. Thilsted.; A, L. Thorne-Lyman. Harnessing global fisheries to tackle micronutrient deficiencies. Nature 2019, 574, 95-8, https://doi.org/10.1038/s41586-019-1592-6.

7. Zamora-Sillero, J.; Gharsallaoui, A.; Prentice, C. Peptides from fish by-product protein hydrolysates and its functional properties: Marine Biotechnology 2018, 20, 118-130, https://doi.org/10.1007/s10126-018-97993.

8. Afsharian, Z.; Khosravi-Darani, K. Biointerface Research in Applied Chemistry 2020, 10, 4790-4802, https://doi.org/10.33263/BRIAC101.790802.

9. Dyer, W.J.; Dingle, J.R. Fish proteins with special reference to freezing. In: Fish as food. Academic Press, New York, Volume 1, 1961; pp. 275, https://doi.org/10.1016/B978-0-12-395569-2.50015-7.

10. Mackie, I.M. The effects of freezing on flesh proteins. Food Reviews International 1993, 9, 575-610, https://doi.org/10.1080/87559129309540979.

11. Shenouda, S.Y. Theories of protein denaturation during frozen storage of fish flesh. Advances in food research 1980, 26, 275-311, https://doi.org/10.1016/S0065-2628(08)60320-1.

12. Abraha, B.; Admassu, H.; Mahmud, A. Effect of processing methods on nutritional and physico-chemical composition of fish: a review. MOJ Food Process Technol 2018, 6, 376-382, https://doi.org/10.15406/mojfpt.2018.06.00191.

13. Abdullah, A.; Naibaho, I.; Kartikayani, D.; Nurilmala, M.; Yusfiandayani, R.; Sondita, M.F.A. Fish quality and nutritional assessment of yellowfin tuna (Thunnus albacares) during low temperature storage. In IOP Conference Series: Earth and Environmental Science 2020, 404, 012074, https://doi.org/10.1088/17551315/404/1/012074.

14. Carrera, M.; Fidalgo, L.G.; Vázquez, M.; Saraiva, J.A.; Aubourg, S.P. Comparative effect of a previous 150$\mathrm{MPa}$ treatment on the quality loss of frozen hake stored at different temperatures. Journal of the Science of Food and Agriculture 2020, https://doi.org/10.1002/jsfa.10465.

15. Al Khawli, F.; Pateiro, M.; Domínguez, R.; Lorenzo, J.M.; Gullón, P.; Kousoulaki, K.; Ferrer, E.; Berrada, H.; Barba, F.J. Innovative green technologies of intensification for valorization of seafood and their byproducts. Marine Drugs 2019, 17, 689, https://doi.org/10.3390/md17120689.

16. Kundam, D.N.; Acham, I.O.; Girgih, A.T. Bioactive compounds in fish and their health benefits. Asian Food Science Journal 2018, 1-14, https://doi.org/10.9734/AFSJ/2018/41803.

17. Gandotra, R.; Koul, M.; Gupta, S.; Sharma, S. Change in Proximate Composition and Microbial Count by Low Temperature preservation In Fish Muscle of Labeo Rohita (Ham- Buch). IOSR J. Pharm. Biol. Sci. 2012, 2, 13-17.

18. Nurullah, M.; Kamal, M.; Wahab, M.A.; Islam, M.N.; Ahasan, C.T.; Thilsted, S. Nutritional quality of some small indigenous fish species of Bangladesh. In: BAU-ENRECA/DANIDA Workshop on Potentials of Small 
Indigenous Species of Fish (SIS) in Aquaculture \& Rice-field Stocking for Improved Food \& Nutrition Security in Bangladesh, Small indigenous species of fish in Bangladesh 2003; pp. 151-158.

19. Siddique, M.N.; Hasan, M.J.; Reza, M.Z.; Islam, M.R.; Boduruzaman, M.; Forhadur, M.; Reza, S. Effect of freezing time on nutritional value of Jatpunti (Puntius sophore), Sarpunti (P. sarana) and Thaisarpunti (P. gonionotus). Bangladesh Research Publications Journal 2011, 5, 387-392.

20. Kirschnik, P.G.; Viegas, E.M.M.; Valenti, W.C.; de Oliveira, C.A.F. Shelf-Life of Tail Meat of the Giant River Prawn, Macrobrachium rosenbergii, Stored on Ice. Journal of Aquatic Food Product Technology 2006, 15, 57-71, https://doi.org/10.1300/J030v15n02_06.

21. Khan, M.A.; Parrish, C.C.; Shahidi, F. Quality Indicators of Cultured Newfoundland Blue Mussels (Mytilus edulis) during Storage on Ice: Microbial Growth, pH, Lipid Oxidation, Chemical Composition Characteristics, and Microbial Fatty Acid Contents. J Agric Food Chem 2005, 53, 7067-7073, https://doi.org/10.1021/jf050082g.

22. Arannilewa, S.T.; Salawu, S.O.; Sorungbe, A.A.; Ola-Salawu, B.B.Effect of frozen period on the chemical, microbiological and sensory quality of frozen Tilapia fish (Sarotherodun galiaenus). Nutrition and health 2006, 18, 185-192, https://doi.org/10.1177/026010600601800210.

23. Saulum, F.K. Hygienic and nutritive value of imported carp fish and the effect of freezing on it comparing with fresh one. Al-Anbar Journal of Veterinary Sciences 2011, 4, 73-82.

24. Benjakul, S.; Visessanguan, W.; Thongkaew, C.; Tanaka, M. Effect of frozen storage on chemical and gelforming properties of fish commonly used for surimi production in Thailand. Food Hydrocolloids 2005, 19, 197-207, https://doi.org/10.1016/j.foodhyd.2004.05.004.

25. Nair, P.V.; Mathew, S. Biochemical composition of fish and shellfish. CIFT. Technology Advisory Series. Central Institute of Fisheries Technology, Cochin 2000, 682029, 14.

26. Xiong, Y.L Protein denaturation and functionality losses. In: Quality in frozen food. Springer, Boston, MA, 1997; pp. 111-140, https://doi.org/10.1007/978-1-4615-5975-7_8.

27. Zamir, R.; Qasim, R.; Ullah, A. Changes in physical and chemical constituents of crab meat during storage at refrigerator temperature (7+/-2 degrees C). Pakistan journal of pharmaceutical sciences 1998, 11, 27-33.

28. Saeed, S.; Howell, N.K. Effect of lipid oxidation and frozen storage on muscle proteins of Atlantic mackerel (Scomber scombrus). Journal of the Science of Food and Agriculture 2002, 82, 579-586, https://doi.org/10.1002/jsfa.1080.

29. Abd, El-Salam.; M.H.; and El-Shibiny, S. Biointerface Research in Applied Chemistry 2020, 10, 4914-4921, https://doi.org/10.33263/BRIAC101914921.

30. Das, K.P. Effect of ambient temperature, icing and freezing on nutrient composition of Rohu (Labeo rohita), Grass carp (Ctenopharyngodon idella) and Tilapia (Oreochromis mossambica) (Doctoral dissertation, B. Sc. Thesis, Fisheries and Marine Resources Technology Discipline, Khulna University, Khulna, Bangladesh) 2009; pp. 20-30.

31. Ågren, J.J.; Al-Amad, H.; Hänninen, O. Fatty acid content and composition of five fish species from the Persian Gulf. Comparative Biochemistry and Physiology Part B: Comparative Biochemistry 1991, 100, 339341, https://doi.org/10.1016/0305-0491(91)90384-P.

32. Bejaoui, S., Ghribi, F., Chetoui, I., Aouini, F., Soudani, N.; El Cafsi, M. Effect of refrigerated conditions on lipid peroxidation and fatty acid composition of clams (Venerupis decussata) tissues. Journal of New Sciences 2018, 57, 3716-3724.

33. Eslami, M.; Hashem, E.Z.; Ghaniei, A.; Sayyah-Atashbeig, H. Evaluation of linoleic acid on lipid peroxidative/antioxidative parameters, motility and viability of rooster spermatozoa during cold storage. Cell and tissue banking 2018, 19, 799-807, https://doi.org/10.1007/s10561-018-9738-6.

34. Jay, J.M.; Loessner, M.J.; Golden, D.A. Modern food microbiology. Springer Science \& Business Media 2008.

35. Chan, W.S.; Toledo, R.T. Dynamics of freezing and their effects on the water-holding capacity of a gelatinized starch gel. Journal of Food Science 1976, 41, 301-303, https://doi.org/10.1111/j.13652621.1976.tb00605.x. 